\title{
Indigenous Cipatat Kolot Society Resilience Based on Leuit in Bogor, West Java
}

\author{
Bahagia1, Rimun Wibowo'2, Fachruddin Majeri Mangunjaya ${ }^{3}$ \\ 1 Universitas Ibn Khaldun, Bogor, Indonesia. E-mail: bahagiagia59@yahoo.co.id \\ 2 STIMMA IMMI Jakarta, Indonesia. E-mail: rimunwibowo@gmail.com \\ 3 Universitas Nasional Jakarta, Indonesia. Email: fmangunjaya@civitas.unas.ac.id
}

\begin{tabular}{|c|c|}
\hline ARTICLE INFO & ABSTRACT \\
\hline Keywords: & The purpose of this research is to investigate the community \\
\hline Leuit; Cultural resilience; & resilience based on Leuit (traditional storage of paddies) in \\
\hline Food resilience; Indigenous & Cipatat Kolot customary community in Bogor, West Java. The \\
\hline knowledge. & $\begin{array}{l}\text { research method exerts an ethnographic qualitative approach. To } \\
\text { assemble data, an in-depth interview with the Cipatat Kolot }\end{array}$ \\
\hline & customary community leaders and observation and \\
\hline Bahagia., Wibowo, R., & documentation was used. The primary information sources of the \\
\hline Mangunjaya, F.M. & research come from the leaders of Cipatat Kolot. The result is that \\
\hline (2020). Indigenous & the Cipatat Kolot community conserves traditional storage, \\
\hline Cipatat Kolot Society & nely leuit as a traditional building to store paddies from \\
\hline $\begin{array}{l}\text { Resilience Based on Leuit } \\
\text { in Bogor. West Iava. }\end{array}$ & because storing paddies in leuit is a traditional heritage from their \\
\hline $\begin{array}{l}\text { in Bogor, West Java. } \\
\text { ETNOSIA: Jurnal }\end{array}$ & forefather. Directly, the cultural value can be nurtured from \\
\hline Etnografi Indonesia. 5(2): & $\begin{array}{l}\text { vanishing amid environmental and cultural changes, which can } \\
\text { encourage people's resilience. When storing paddies, there are }\end{array}$ \\
\hline $349-365$ & $\begin{array}{l}\text { rules like people must keep half of the overall paddy yields in leuit, } \\
\text { and a half of paddy yields must be store at home. People can }\end{array}$ \\
\hline $\begin{array}{l}\text { DOI: } \\
\text { 10.31947/etnosia.v5i2.11377 }\end{array}$ & $\begin{array}{l}\text { directly adapt to climate, environmental issues, and eco- } \\
\text { catastrophe because they have ample staple food in traditional } \\
\text { storage and house. }\end{array}$ \\
\hline
\end{tabular}

\section{Introduction}

Climate and environmental issues can be identified as great obstacles, both locally and globally. Climate variability is a variation in climate, including the normal highs and lows, wet and dry periods, hot and cool periods, and extreme values. It can range from day-to-day variability and to year-to-year variability (File \& derbile, 2019). Meanwhile, environmental issues include social change because of the globalisation of technology, vanishing of culture, and losing of local knowledge as well as emerging pollution. Climate change, ocean acidification, species extinction, and changing precipitation patterns are increasingly affected by human well-being (Garmestani et al., 2020). 
Climate dynamics has implications to livelihoods of indigenous people who rely heavily on wild resources (Carothers et al., 2014).

Besides that, indigenous knowledge inhabits location where site is prone-disaster including in hill of mountain, ravine, and side of river. However, indigenous knowledge with local understanding, community enables to confront climate, environmental predicament as well as eco-catastrophe. Even globalization of world but the community still restrains their culture, belief, knowledge, behaviour and ritual. Local knowledge has combated climate and environmental issues for long term which are initiated by their forefather. Local people with knowledge locally try to observe natural clues including animal behaviour to determine climate and season. The aim is to save the life from the environmental and climate changes. The impact is that knowledge has appropriated to environmental change, and it assists them people from hardship condition. Most of this knowledge was transmitted over successive generations and became a part of living, culture, and religion sustenance (Inaotombi \& Mahanta, 2019).

Local knowledge has experimented to reach community resilience because knowledge encompasses behaviour and real action to tackle environmental issues. Local knowledge as the local policy has been tested to reduce the rate of environmental disturbances and has a permanent way to attain resilience. Meanwhile, resilience is the ability to survive future natural disasters with minimum loss of life and property as well as the ability to create a greater sense of place among residents, a stronger, more diverse economy, and a more economically integrated and diverse population (Tammar, Abosuliman \& Rahaman, 2020). Resilience refers to the coping mechanisms and adaptive capacities that provide the means to overcome the exposures and sensitivities associated with vulnerability (Doherty et al., 2019).

In this sense, resilience may be defined as the capacity of a system such as to bounce back to a stable equilibrium point and to absorb the perturbation in order to reach a new equilibrium (Östh et al., 2018). Resilience as a process is characterized by adaptive capacity, whereby systems are modified to ever-changing circumstances (Wenger, 2017). Resilience also includes persistence and recovery to face environmental change (Hellin et al., 2018). Resilience encompasses persistence, adaptation, and transformation processes as potentially complementary rather than conflicting (Leite, Ross, \& Berkes, 2019). Absorption is used to refer to an actor's or community's ability to decline the adverse impact of shocks and stresses through appropriate and successful coping strategies (Tarusarira \& Manyena, 2016). Resilience can result in the interaction between three capacities including absorptive capacity, adaptability, and transformability (Béné et al., 2014).

There are five components of resilience, namely resistance, coping strategies, adaptation, adaptive preference, and transformation (Béné \& Doyen, 2018). Absorptive is also connected to overcome climate-related shocks or stresses while and after they occur, and adaptive has connection to power to adapt in long period climate risks, as well as the ability to learn and adjust after a disaster for declining susceptibility in the 
future (Ulrichs, Slater, \& Costella, 2019). Resilience refers to the coping mechanisms and adaptive capacities that provide the means to overcome the exposures and sensitivities associated with vulnerability (Doherty et al., 2019). Meanwhile, maintaining ecological resilience and adaptive capacity at the same time meets human needs (Gillson, Whitlock, \& Humphrey, 2019).

Another part of resilience includes persistence, resistance, and recovery (Ungar, 2018). Resistance describes a process whereby a system is at risk of being overwhelmed by internal or external stressors and must actively use its resources to resist creating new regimes of behaviour (Ungar, 2018). Besides that, resilience also has connection to social capital. Social capital including social cohesion, effective local governance, and capacity for collective actions can create resilience (Béné et al., 2016). Anticipating and coping with shocking impacts, it is equally important to strengthen both the adaptive (adjustment strategies) and transformative (system-level change) capacities to ensure long-term resilience in the study of communities (Asmamaw, Mereta \& Ambelu, 2019).

Indigenous knowledge has experience in the past to overcome life perturbances including disasters and climate. They applied knowledge to real action including a local-based season calendar, forest conservation like a prohibition zone, use of local paddy varieties, and learning by action as well as learning from failure. Indigenous knowledge also has the ability for interpreting natural events and phenomena. Seasonal cropping calendars, crop choices are influenced by traditional forecasting, namely heights of ant nests which informed forecasting of rainfall and rainy season (Bang, Miles \& Gordon, 2018).

The impact is indigenous knowledge releases absorptive as short-term action to react resilience as well as persistence to retain for preserving culture and knowledge. Even, the knowledge adapts to long period planning to prefer actions to cope with perturbances for attaining community resilience instead of individual resilience. In food system resilience, indigenous knowledge combats unexpected events through absorptive and adaptation to hurdles. There is local knowledge that can be utilized as exemplary to react to community resilience including Zunde raMambo, which is a local institution that empowers laxity person through distributing nature resources like land. The vulnerable community will be permitted to cultivate the land.

The labour in Zunde raMambo schemes improves the absorptive capacity of the community to save human lives from food insecurity induced by drought and flood. The Zunde raMambo scheme creates food reserves for vulnerable people (Mavhura, 2017). In addition, Zunde whose seeds are obtained from the previous harvests and preserved uses indigenous knowledge by hanging them in the traditional kitchen roof. The aim is to feed infants, disableds, and old people as well as to booster the bereaved (Lunga \& Musarurwa, 2016). Another culture which is imperative to food resilience is Kerne culture. In this culture, people dry cassava as basic food to combat the disasters. Socially, people work together to produce food (Ohleky, Pattiselanno, Kaplale, 2017). It is resilience because it ensures staple food to tackle uncertain events. 
Furthermore, indigenous knowledge has proof to observe natural clues to predict climate, season, and environmental perturbances. As a consequence, indigenous knowledge enables to adapt climate variations and environmental dynamics to react to community resilience. In Dani tribe, if the position of the sun is at the top of the mountain (north) then the dry season will arrive in the near future, and if the position is increasingly leaning towards the southeast direction, then signifying summer will last long. Otherwise, if its position is leaning towards the west, then the rainy season will arrive in the near future (Veronika, 2013). Lastly, resilience may be conferred by diversifying crops and livestocks and by farmers implementing adaptive approaches in response to perturbations (Bullock et al., 2017). A lack of diversity was considered to be a threat to the resilience of food systems. It is easier to diversify crop production actions for increasing resilience, but the farm management of capital and workintensive animal production are less easily buffered with more diverse farm actions (Himanen, Rikkonen \& Kahiluoto, 2016). Diversity is characterized by a variety of crops, markets, sources of inputs, and spatial heterogeneities.

In another indigenous knowledge like in Ciptagelar customary society, community exerts communal leuit or traditional place to store paddies for creating society resilience. Nopianti (2016) reveals that communal Leuit has pivotal roles as a major place for storage of paddies for community. Typically, for communal leuit has functions to attain social solidarity because paddies in communal leuit are used for mutual assisting when the members of community need basic food. As a result, there is no hungry person in Ciptagelar society because each person is mutually shouder and shouder in eradicating hunger and poverty in social environment. In this research, it was investigated resilience customary society of Cipatat Kolot based on leuit. The objective of this research is to discover the role of leuit (traditional paddy storage) to create community resilience for confronting eco-catastrophe, flooding, and drought as well as another ecological disaster. Secondly, this is to find out cultural resilience through the tradition of storing paddies in leuit. Another is to investigate the reacting food resilience based on paddy yield distribution in Leuit for adapting environment dynamics in both long and short-term periods. Eventually, this is to know about local policy when paddy yields are stored in leuit and its connection to society resilience.

\section{Method}

The research about Indigenous Cipatat Kolot Society Resilience Based on Leuit in Bogor, West Java exerts ethnography with a qualitative approach method. The research is conducted in Urug village, Sukajaya Subdistrict, Bogor Regency, West Java, Indonesia. Ethnography is an applied and pragmatic form of ethnography that explores a specific social phenomenon as it occurs in everyday life (Bikker et al., 2019). Ethnography is used when the subject involves an entire cultural group. It focuses on describing the cultures and customs of people (Mohajan, 2018). The role of the ethnographer, therefore, is to watch, listen, take part in daily life and ask questions to collect data, throwing light on a particular research issue (Bell \& Aggleton, 2012). 
Meanwhile, qualitative research has a rich tradition in the study of human social behaviour and culture. In order to gather data in the field, the researcher uses three sorts of method including observation, in-depth interviews, and documentation. Observation is implied through some activities such as the researcher observes directly the location of leuit as traditional storage of paddies, and the researcher observes the location of local paddy production as well as an area for drying paddies like using lantayan. The researcher notes all data about the way to store paddies in leuit and the rituals before and upon locating the paddies in leuit. The researcher also mingles in customary community action. It can be strengthened by researcher's joint in cultivating local paddies with the community to understand the way local people plant the paddies. Secondly, were conducted in-depth interviews with the key personnel including Chief of Cipatat Kolot Society and Abah Nurhasim. The two key people deem that they can explain profoundly about traditional storage (leuit) which has a heavy connection to community resilience for confronting climates and reacting to food resilience.

Abah Sacim is selected because he is deeply knowledgable about the culture because he was the direct offspring from previous chief. When in-depth interviews are conducted, the researcher uses equipment such recorder and mobile phone for recording the voice of both of informants. Data are collected related to tradition and culture of Cipatat Kolot to store paddies in leuit as a traditional storage. It has an imperative role to combat environmental change and life obstacles because the community can react to cultural resilience. The impact is that their culture and tradition can encourage the community to overcome the perturbances. Another is to find the relation between leuit for achieving food resilience. Tradition and culture of people like behaviour for storing paddies can underpin food resilience because people avoid the scarcity of food. Besides that, the research will look for the rules for storing paddies in leuit and its linkage to resilience for food, environment, as well as climate dynamics. Furthermore, data will be bolstered by numerous sources such as international journals and national journals, books, and data which are severely connected with a traditional community of Cipatat Kolot.

Thirdly, the researcher exerts documentation. In this method, the researcher uses camera for taking pictures or photos, typically photos of leuit and lantayan. The images of leuit and lantayan can be supported by data from observation and interview. Once the data have been collected, the researcher checks the data and starts to validate them. However, the researcher must go back more than 5 (five) times to ensure that the informants will not anymore change the statements that they have uttered. In this section, the researcher uses some strategies, like visiting the locations and asking again the same questions but in a different time. For example, as the researcher has interviewed the informants in daylight previously, in another time, the informants will be asked in the morning. Even the researcher comes to the field with another person whom the informants do not know that the person will ask the same questions. The data are probed by triangulation data for having trusted data. Triangulation can be mentioned as mixing some sources of research methods to obtain valid data. There are three sorts of triangulation including sources, technique, and time (Sugiyono, 2016). In 
this reseach, the combination data from observation, in-depth interview, and documentation can be be believed as valid data.

\section{Result and Discussion}

\section{Tradition and culture resilience in leuit building}

Chief of Cipatat Kolot and his family store paddies in leuit is tradition and culture from their forefather. Tradition and resilience have a connection. Cultural resilience comprises identity, spirituality/worldviews/values/beliefs, and traditions/languages (Jogen et al., 2019. The chiefs of Cipatat Kolot people typically have chores to pursue their mandates from ancestors to continue the tradition for storing paddies and preserving leuit as a traditional storage amid globalisation. It is linked to attain cultural resilience because buildings like leuit can preserve food for people and conserve Leuit as a heritage from their forefather culture. Cultural heritage can help people adapt to new circumstances and absorb adversity in their own lives (Holtorf, 2018). Cultural resilience is regarded to preserve culture and tradition for creating society resilience without vanishing the culture. Leuit contains cultural and tradition values because it is the real product of Cipatat Kolot culture and which has an advantage to human life. In the outside of the community, the farmer has vanished the culture because storing paddies in leuit is no longer implemented.

Meanwhile, customary societies like Cipatat Kolot have a habit from their forefather to distribute paddies to leuit for securedly fundamental food. Another reason is that storing paddies in leuit has meaning for pursuing their forefather's mandates. It has relation to tradition because the behaviour has occurred in the previous period, but the habit can still be pursued recently. Abah Sacim as leader of Cipatat Kolot is as receiving person directly from his forefather. Even, he is convinced that there is a bad impact on him when he halts the tradition. It has conservation of values because outside of the society has changed its behaviour to no longer store paddies in traditional storage any more like in Cipatat Kolot. The existence of leuit in Abah Sacim is ironically severe because they live near the capital city of Indonesia namely Jakarta, whose the culture has mixed among numerous cultures from western culture to local cultures. Besides, the farmers in Bogor, West Java and other regions in West Java province do not implement the tradition like constructing leuit close to their houses. It can be compounded by the culture which has experienced extinction in farmers outside of customary societies.

Wiradimadja (2018) remarks that modern life trait in downtown has deteriorated the values of culture especially in West Java, where the Sundanese tribe lives. When the customary society's generation protects and nurtures this tradition, the generation has an endeavour to protect forefather's heritage culture and tradition without the extinction of storing paddy behaviour. The other is that leuit building can be categorized as performing physically in culture. The physical culture has a role to save a person from hunger because there is an action to store paddies for ensuring fundamental necessities for the person. Beside, leuit can be mentioned as conserving 
tradition because there are rituals before storing paddies in leuit. People burn frankincense at the first time when locating paddies with panicles to leuit. There are some purposes including the way to put to sleep the paddies and another objective is to avoid the paddies from some insects like rodents. Meanwhile, rodents have a pivotal role to damage the paddies.

The smell of frankincense can evict rodents from leuit. The ritual is conducted again when the people intend to gather some paddy yields which have been allocated to leuit, and the people cannot admit directly to collect them. They believe that paddies have a soul like a human; Abah Sacim said that if we are struck by another person, we feel it painful. It is the same with paddies, as paddies convert to rice using mortar, people have acted abusively to paddies, and paddies experience the pain. To avoid this, people burn frankincense and pray to good. Abah as a leader believes that it can vanish the pain sense from paddies. Conversely, the paddies are raised again when human needs rice. In this step, a human must burn frankincense again. Generation, like Abah Sacim, protects the leuit which contains conserving building of leuit, the message from the ancestors, and pursuing ritual as a tradition in culture has a proof that the generation achieves culture and tradition resilience. It is an effort to adjust the culture without devastating the culture, and it is the endurance of culture (Puspitasari, 2018).

Eventually, the tradition has linkage to avoid people from disasters because the ecological disasters including flooding, land slide, and fire impacts to weaken the levels of livelihood of people. The building of leuit and the house have distance. The separation has objectives, including avoiding leuit building which contains paddies to be devastated by disasters like fire. As the house building and leuit are not split, the house and leuit building experience damaging at the same time. However, this building is close to house building, but there is a range between the two buildings. The house is damaged, but the stock of food in leuit is still secured from occurrences like life disasters. It has heavy linkage to tradition for assisting people to go beyond from life perturbances including scarcity of food. The action includes preparedness of societies before disasters combating people's life. It is an effort to anticipate disasters by adjusting the efficient steps (Tamitiadini, Dewi, \& Adila, 2019). In these steps, people have provided food before disasters, and tradition like storing paddies in leuit can save paddy stocks when disasters combat human life. However, the cultural resilience will be weakened if the cultural system weakens (Asha et al., 2018). As the Cipatat Kolot no longer implements this tradition, it pursues to the extinction of a culture.

\section{Resilience for food and environmental change based on leuit}

Local knowledge has been adapted to environmental change and climate dynamics through real actions of local people to tackle these perturbances. People observe the change and suit the actions with an alteration. They also conduct an experiment locally to tackle environmental issues. Meanwhile, environmental issue encompasses social change, cultural change, and ecological change, life obstacles as well as ecological disasters like flooding. Indigenous Cipatat Kolot community confronting hurdles 
exerts preserving culture and tradition like functioning leuit. Leuit can be mentioned as traditional storage of paddies in Sundanese tribe, typically which is conserved nowadays in indigenous societies like in Cipatat Kolot. It is a tradition of Sundanese tribe for depositing paddies in leuit as fundamental food stock until meeting again the new schedule for cultivation.

The fundamental principle is to distribute dried paddies rather than rice. It plays a pivotal role to preserve local paddies because the paddies which are stockpiled in leuit must be the local paddies. Ecologically, it can bolster the conservation of local biodiversity like local paddies from vanishing amid globalization. As a consequence, people can combat life obstacles through aplicating traditional knowledge. In agriculture, typically in post-harvest of paddy, local people attain food system resilience due to their application of local knowledge to ensure basic necessities. Leuit in traditional people like Cipatat Kolot community is implied to store paddy as the staple food for facing environment hurdle.

Leuit building is made from natural materials such as wood, bamboo wave, and roof from palm leaves. There are some parts of the building, including the roof of the building, frame of leuit, floor, and feet of leuit. Another part of leuit is the door. The function of leuit is just for storage in long term, and paddy must be traditionally dried before entering paddy grain to leuit. Chiefs of Cipatat Kolot and their family storing paddies in leuit is tradition and culture from their forefather. Tradition and resilience have a connection. The picture of leuit can be viewed in Pictures 1,2 and 3 below.

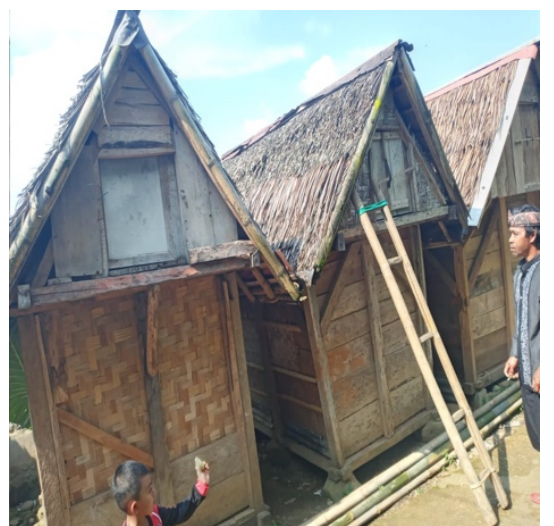

Picture (1)

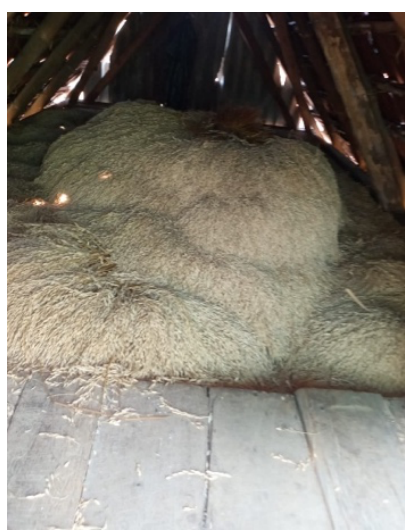

Picture (2)

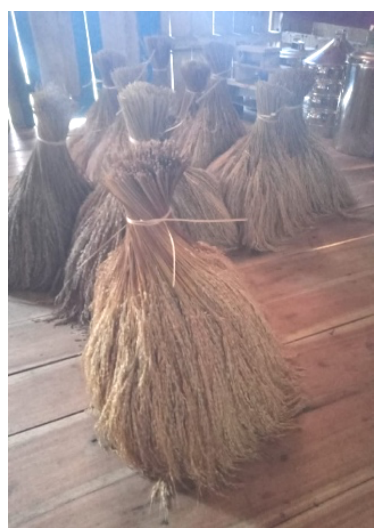

Picture (3)

Picture (1): traditional storage of paddies (leuit)

Picture (2) paddies in leuit

Picture (3) Panicles of paddies before placed into leuit

There is a connection between culture and food security (Mc Cubbin, 2017). A tradition like storing paddy grains to create food security can support resilience based on culture but impact to community resilience. In addition, jumping resilience to catastrophe and disasters must be encouraged by social infrastructures at the community level (Aldrich \& Meyer, 2014). Leuit is a traditional building to overcome disasters. Even, leuit is a building for keeping dried paddies, but it also boosts people 
in Cipatat Kolot for confronting environmental disturbances because leuit salvages paddy grains from being devastated. Even, this building preserves the quality of paddies from decay because basic food which will be saved from flooding because leuit is a stage building. Worstell \& Green (2017) stated that resilience accumulates reserves and physical infrastructures that enable withstanding disturbances.

There are some benefits when people store paddies in leuit such as paddies will be free from insects and rat attacks. Another is to ensure that paddy grains will not contact with land directly because there are feet of leuit. As a consequence, paddies will not easily get deteriorated. The other is the rate of moisture in leuit is severely constant, as well as paddies will avoid flooding disaster. The other is the circulation of air inside leuit runs properly. It leads to protect paddy grains from decaying. Unfortunately, in outside, Cipatat Kolot people have vanished tradition and culture, and farmers have not comprehended to store paddy traditionally. They will not convert their knowledge to other knowledge because they are consistent to follow their footprinted forefather.

The fundamental principle is to pursue their father's message and not change it. The capacity is to adapt to new challenges without losing biological and cultural wealth and productive capacity (Valés-Planells, Galiana \& Díez-Torrijos, 2019). In Cipatat Kolot people, paddies will be stored in Leuit after harvesting paddies in the field. There are some steps that Cipatat Kolot people conduct before locating paddies to the traditional appliance. Initially, Cipatat Kolot people collect paddies from the field. They will let paddies with panicles naturally in the vicinity of rice paddy fields for drying under the sun in Lantayan appliance. This treatment is to decline the rate of liquid in paddy grains manually. Generally, as sunshine is fully bright, paddies will dry around 14 days after they let paddy in this tool. Conversely, as sunshine is murky, people need to let paddies in a rice paddy field under lantayan about 30 days or 1 month. The picture of lantayan can be viewed in picture 4 below.

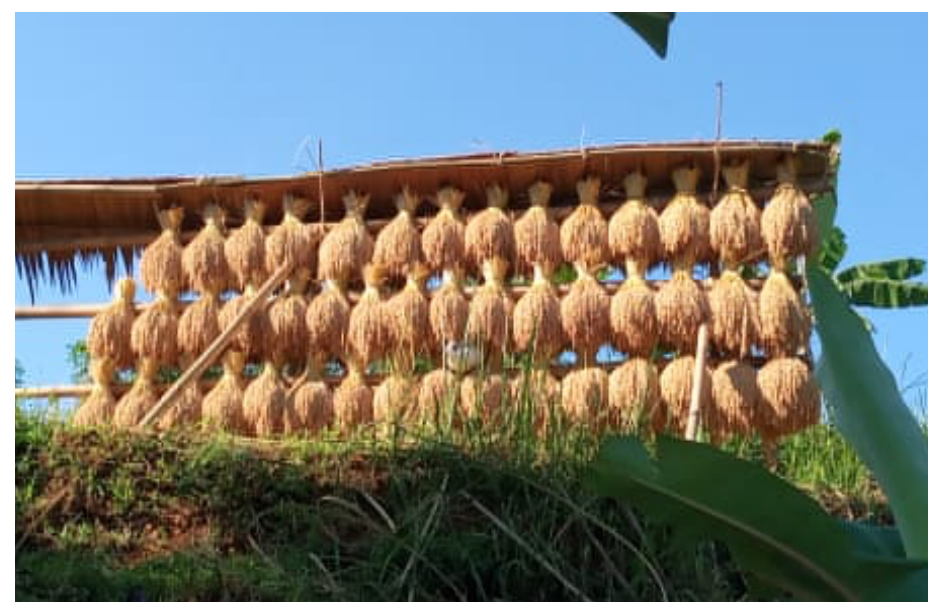

Picture 4. Naturally drying equipment (lantayan).

Lantayan is distinguished with a modern method like drying machine or floor drying. Lantayan is traditional drier for paddies which paddies are collected by etem (ani-ani). It is unable to utilize lantayan if paddies are collected without panicles. Lantatan has 
numerous advantages, such as paddies will not moist anymore because all paddy bindings will be hung naturally in lantayan. Paddies which are gathered with a sicklelike national paddy variety enable to imply lantayan for drying because paddies cannot be hung. It is just for traditional paddies in traditional community. The rate of paddy liquid in paddies will not be insisted for losing because liquid of paddies will vanish step by step. Even sunshine will not quickly contact to paddy grains because sunshine will fall initially on the roof of lantayan. The impact is water content in paddies will vanish without being insisted. Another advantage is that paddies can avoid rain directly because rain will contact with the roof of lantayan.

Furthermore, it lavages from the sprinkles of rain from the surface of the land. The other is that paddies are unable to decompose because paddies are not entered to gunny sacks after harvesting. In Cipatat Kolot, people are stringent to determine periods of harvesting because it has a strong connection to quality of paddies when paddies are stored in traditional storage. Abah Nurhasim as the key person said that they garnered paddies when paddies are benar asak (mature). This means that paddy grains must be gathered after grains of paddy are really fully mature. The rate of water in paddy contents is the highest in this period. Meanwhile, paddies which are highrated liquid are easy to deteriorate and experience shrinkage in the processing steps of paddies (Suwati, Wiryono, \& Romansyah, 2018). In this time, seeds will not rely on paddy trees for nutrients (Nuno, Raka, \& Yuswanti, 2017). Another clue to indicate that paddies have been ready to be gathered is the remains of paddies, and the paddy panicles have been converted from green to yellow in colour (Kobarsih \& Siswanto, 2015).

Furthermore, merits are to circumvent paddies from disease attacks because paddies will be dried by sunshine and better circulation. The other step is paddies from Lantayan are carried out by man for paddy storage in traditional storage. In this step, there is a ritual stewardship action which is conducted by the leader of Cipatat Kolot people before locating paddies to Leuit. The purpose is to raise gratefulness to goodness because they obtain abundance of paddy yields and expect that they will acquire similar yields in forthcoming. The stewardship role would help conserve a unique indigenous culture (Cordero et al., 2018). Overall of paddy income will not be consumed, but people will store a part of paddy yields and consume the other part of yields. Paddy yields must be split into two categories, namely a half of overall yields have to be stored inside leuit, and a half of another outcome must be stored in the house. If chiefs of the society obtain paddy yields about 300 bunches, 150 bunches must be stored in the traditional storage, and 150 bunches are carried to inside of the house.

The outcome of this paddies is adequate to fulfil their household family. Abah Sacim remarks that his family has not ever purchased rice to fulfil basic need. Although they obtain paddy yields, they still work hard to look for basic food from other sources other than paddy yields. It will not dramatically decrease the paddy yields which have been collected. Storing paddies for food safety can be identified as the resilience of community because post-harvest is the food system. It presents the opportunity to 
eradicate weaknesses and build capacities in the food system while dealing with future uncertainty (Tendal et al., 2015).

There are three kinds of resilience including absorptive, adaptive, and transformative. Absorptive is linked to the ability to decrease the level of shocks and find a way to recover when shocks actualize (Ansah, Gardebroek, \& Ihle, 2019). Meanwhile, adaptive includes the power of community to anticipate shock before occurring and cope with this shock in forthcoming (Jeans, Thomas, \& Castillo, 2016). As staple food is provided in a traditional store like this, trait can impact the capacity of people for surviving when environmental change and life perturbance occur, including ecological disaster like flooding as well as climate change.

Paddies will be distributed both in leuit and at home. There are numerous purposes of this action including people provide stock food when there is a grieving family around them, namely they family experiencing death. People can exert stock at home to assist the family which experiences severe sorrow. The action like this is absorptive for resilience because they store paddies for combating short period disturbance. Besides that, stock of paddies can save them from hunger when eco-catastrophe combats community unpredictably. Preparedness leads to readiness for resilience ( $\mathrm{O}^{\prime}$ Connor et al., 2016). Cipatat Kolot people release early action to face catastrophe through guarantee of food stock at home and traditional storage. Meanwhile, early warming and early action such as responding to community priority and plan can be categorized as resilience (Ewbank et al., 2019). It is a principle of adaptation to cope with unexpected circumstances (Salomon et al., 2019).

Cipatat Kolot people have adjusted this mechanization to overcome forthcoming disturbances before they occur to beat them. The ability of a food system to respond and adapt to disruptions, while maintaining its function, describes the system's resilience (Schipanski et al., 2016). Adaptive capacity includes abilities to anticipate and recognize disruptive events and re-organize to handle these events (Blok, Sharpanskykh, \& Vert, 2018). Another value of resilience is linked to the tradition of Cipatat Kolot people for providing food to people who visit their house like a guest from outside and inside of the community. There is a sense of social belonging in people for other people including other families inside and outside the community. They will serve people who ever visit their house. The principle is to glorify guest. It can enhance resilience based on the community because there is social capital like social binding among them.

It can be connected to traditionally social security for assisting people by providing provision of food (Mavhura, 2017). The tradition of Cipatat Kolot people has enhanced community resilience through preferring temporary food for people outside and inside when other families or people visit someone's house. Behaviour in providing provision of food for people can be categorized as resilience because other people can heal starvation temporarily. It can be bolstered by Cipatat Kolot people who still have ample stockpiles at home to confront environmental crisis, life obstacles, and other life issues because they distribute some food at home rather than trade it in the public 
market. It can be strengthened by the staple of food in leuit which is available for consumption as basic food stock at home which has been expended by people. Ansah, Gardebroek, \& Ihle (2019) said that adequate food consumption ensures good health and ability to work, leading to higher income and accumulation of assets to deal with uncertainties.

Meanwhile, food and nutrition security builds resilience in a society when people have access to safe and nutritious foods (Raheem, 2018). Directly, it scales up of people's capacity to attain resilience to numerous kinds of perturbances. It is the survival strategy of indigenous people because they store food (Kuyu \& Bereka, 2019). Besides that, diversification of strategy like storing some paddy grains as food at home and in leuit is a livelihood strategy. When key person of Cipatat Kolot separates which food for direct consumption and which one for that of the forthcoming has connection to avoid people from starvation. In other rules, types of paddy which are stored in leuit are local paddies including Sri Kuning and Raja Wesi. It connects to a social policy like the rules in the community to preserve local paddies (biophysics) rather than modern paddy varieties. The ability of society and biophysics is a resilience to cope with stressors (Folke, 2016). In addition, people utilize local biodiversity, which is local food's cultural and ecological systems (Tremblay, Landry-Cuerrier, \& Humphries, 2020). The policy must be encouraged that paddies may not be collected until 100 days from the first day of harvesting when they are stored in leuit. It means that person will not be allowed at any time to visit leuit for gaining paddies. As stocks have been expended by households, people allow wielding stocks in leuit. Unfortunetly, this valuable knowledge have not implemented anymore in all of individual but abah Sacim as leader of Cipatat Kolot still preserve the knowledge from vanishing.

\section{The rules of storing paddies for resiliences}

Storing paddies in leuit has some local rules to encourage quality of paddies and avoid from decay. Firstly, new paddy yields and old stocks will be distinguished by layers as well as using indung paddy (mother of paddy). In Cipatat Kolot people, mother paddy is the paddy which is gathered in the field from the first time when these people cultivate the paddies. There is a tradition of paddy cultivation in Cipatat Kolot where the leader of Cipatat Kolot will create a sign, which Cipatat Kolot people mention as punpuhunan. There are numerous plants that can be used including dadap trees, taming trees, and other trees. The principle is to give a clue where the location the first time the people farm paddies is. In this sign, Cipatat Kolot people must begin collecting paddies from where they initially plant the paddies. Paddies must be gathered by farmers around 7 panicles in the vicinity of punpuhunan. The seven (7) panicles of paddies from this zone must be laid in the middle of inside leuit before filled by other bunches of paddies (paddies with panicles which are bound). The paddies which have been collected must be dried for waiting all bunches of paddies to be completed to collect. As the paddies have been finished including drying all paddies, one bunch or one binding of paddies must be mixed to mother of paddy, which is collected firstly. These bunches have to be stored in leuit initially before being 
filled by another paddy yield. In the vicinity of mother, paddies will be surrounded by new stocks.

This will be filled continuously until leuit cannot be filled with another paddy. As the old stocks are ready in leuit, people will let them in the first layer and continue to the new yields of paddy. This means that on the top layer in leuit is old stocks, and on the lowest layer is new yields of paddy. People will take old stocks in leuit when they are eager to consume rice. The rules are to spend the old stocks, but these people also consume new stocks because they have to bring some to home. The aim is to evade the paddies from degrading because old stocks are easier to decay compared to the new yield. The tastes of paddy can be unflavored when consuming the outdated stocks. In these rules, the people withstand the quality of food for consumption because they will not eat food which is from the outdated stocks. Food quality is another example in which the natural system provides for resilience (Kelley, 2013). When people are healthy, people evade from diseases. From this finding, it can be shown that Cipatat Kolot community has achieved food security based on local action because they have local rules that people are not allowed to take paddies in leuit carelessly.

\section{Conclusion}

Indigenous people combat life difficulties through knowledge which is released in real action based on real experience. The knowledge has experimented and observed environmental and climate changes as well as life hurdles. The knowledge is similar from the first generation to the last generation, transferring belief, culture, knowledge, and behaviour without documentation, but generation learns from observing real actions of their forefather in the field and in an oral manner. There are numerous points of view that can be inferred from the result of this research. First, encompassing leaders of Cipatat Kolot have preserved tradition and culture like the building of leuit amid culture perturbance from outside of the community. Directly, it preserves ritual before and after pouring of paddies in leuit. When nurturing leuit, it pursues the existence of tradition and culture which have been handed down from their forefather, and attains culture resilience. Secondly, traditional storage building is resilience because traditional building like leuit is used for storing paddies as food stock from being devastated. Even paddies avoid disasters like flooding because the traditional building like leuit is a stage building. It can pursue to react to cultural resilience because the generation preserves storing paddies in this traditional storage.

Directly, food resilience can be attained because people will not be insufficient of food, due to the local policy that people must store a half of overall paddies outcome in this storage, and a half of paddy yields are stored at home. People are also disallowed to take paddies in leuit except paddies in leuit have been about hundred days. Paddies are stockpiled in this building for adapting both long and short-term periods. The impact is that health people resilience can be achieved because person will consume ample of food. Then, there is policy before locating paddies including that of for people who need to provide mother of paddy. The position of mother paddy must be in the centre inside leuit. Meanwhile, new paddy yields must be stored in the vicinity of mother 
paddy until vacant space inside leuit is filled fully by paddy. While old stock paddy which has not been consumed and must be stored on the top layer inside leuit, and new paddy yields must be under a layer of old stocks. The purpose is to ensure the quality of food for daily consumption.

\section{Acknowledgement}

The finding in this research is the expression and conclusion based on author perspective. It doesn't link to the organization where the author work or any another institution have bolstered for providing this research paper. Thank also to LPM Equator Bogor which have bolstered for funding to release the research in Urug societies Bogor West Java.

\section{Conflicts of interest}

Author declares no conflict of interest.

\section{References}

Aldrich, D.P., \& Meyer, M.A. (2014) Social Capital and Community Resilience. American Behavioral Scientist, 1-16.

Ansah, I.G.K., Gardebroek, C., \& Ihle, R. (2019) Resilience and household food security: a review of concepts, methodological approaches and empirical evidence, Food Security, 11, 1187-1203.

Asha., Mabruri, K., Komariah, N., \& Imron, A. (2018). Construction of Cultural Resilience through the Exploration of Seblang Olehsari Banyuwangi Ritual Philosophical Value. Komunitas: International Journal of Indonesian Society and Culture 10(2), 255-262.

Asmamaw, M., Mereta, S.T., \& Ambelu, A. (2019) Exploring households' resilience to climate change-induced shocks using Climate Resilience Index in Dinki watershed, central highlands of Ethiopia, PLoS One, 14 (7), 1-21.

Bang, H.C., Miles, L., \& Gordon, R. (2018). Enhancing local livelihoods resilience and food security in the face of frequent flooding in Africa: A disaster management perspective, Journal of African Studies and Development, 10 (7), 85-100.

Bell, S.A. \& P. Aggleton. (2012). Integrating Ethnographic Principles In Ngo Monitoring And Impact Evaluation. Journal of International Development 24, 795-807.

Béné, C., \& Doyen, L. (2018). From Resistance To Transformation: A Generic Metric Of Resilience Through Viability, Earth's Future, 6 (7), 979-996.

Béné, C., Al-Hassan, R.M., Amarasinghe, O., Fong, P., Ocran, J., Onumah, E., Ratuniata, R., Tuyen, T.V., McGregor, J.A., and Mills, D.J. (2016). Is resilience socialy constructed? Empirical evidence from Fiji, Ghana, Sri Lanka, and Vietnam, Global Environmental Changes, 38, 153-170.

Béné, C., Newsham, A., Davies, M., Ulrichs, M., \& Godfrey-Wood, R. (2014). Review Article: Resilience, Poverty And Development, Journal Of International Development, 26 (5), 598-623.

Bikker, A.P., Atherton, H., Brant, H., Porqueddu, T., Campbell, J.L., Gibson, A., McKinstry, B., Salisbury, C., \& Ziebland, S. (2017). Conducting a team-based multi-sited focused ethnography in primary care, BMC Medical Research Methodology, 17 (139), 1-9. 
Blok, A., Sharpanskykh, A., \& Vert, M. (2018). Formal and computational modeling of anticipation mechanisms of resilience in the complex sociotechnical air transport system, Complex Adapt Syst Model, 6 (7), 1-30.

Bullock, J.M., Dhanjal-Adams, K.L., Milne, A., Oliver, T.H., Todman, L.C., Whitmore, A.P., \& Pywell, R. (2017). Resilience And Food Security: Rethinking An Ecological Concept, Journal Of Ecology, 105 (4), 880-884.

Carothers, C., Brown, C., Moerlein, K.J., López, J., Andersen, D.B., \& Retherford, B. (2014). Measuring perceptions of climate change in northern Alaska: pairing ethnography with cultural consensus analysis, Ecology and Society, 19 (4), 27.

Cordero, R.L., Suma, M., Krishnan, S., Bauch, T.C., \& Anand, M. (2018). Elements of indigenous socio-ecological knowledge show resilience despite ecosystem changes in the forest-grassland mosaics of the Nilgiri Hills, India, Palgrave Communications, 4 (105), 1-9.

Doherty, B., Ensor, J., Heron, T., \& Prado, P. (2019). Food Systems Resilience Towards an Interdisciplinary Research Agenda, Emerald Open Research, 1 (4),1-17.

Ewbank, R., Perez, C., Cornish, H., Worku, M., \& Woldetsadik, S. (2019). Building resilience to El Niño-related drought: experiences in early warning and early action from Nicaragua and Ethiopia, Disasters, 43 (S3), S345-S367.

File, D.J.M., \& Derbile, E.K. (2019). Sunshine, temperature and wind Community risk assessment of climate change, indigenous knowledge and climate change adaptation planning in Ghana Dramani J.M, File National Disaster Management Organization, 12 (1), 22-38.

Folke, C. (2016). Resilience (republished), Ecology and Society, 21 (4),44.

Garmestani, A., Craig, R.K., Gilissen, H.K., McDonald, J., Soininen, N., DoornHoekveld, W.J.V., \& Rijswick, H.F.M.W. V. (2019). The Role of Social-Ecological Resilience in Coastal Zone Management: A Comparative Law Approach to Three Coastal Nations, Frontiers in Ecology and Evolution, 7 (410) , 1-14.

Gillson, L., Whitlock, C., \& Humphrey, G. (2019). Resilience and fire management in the Anthropocene, Ecology and Society, 24 (3), 14.

Hellin, J., Ratner, B.D., Meinzen-Dick, R., \& Lopez-Ridaura, S. (2018). Increasing socialecological resilience within smal-scale agriculture in conflict-affected Guatemala, Ecology and Society, 23(3), 5.

Himanen, S. J., Rikkonen, P., \& Kahiluoto, H. (2016). Codesigning a resilient food system, Ecology and Society, 21(4),41.

Holtorf, C. (2018) Embracing change: how cultural resilience is increased through cultural heritage, World Archaeology, 50 (4), 639-650.

Inaotombi, S., \& Mahanta, P.C.. (2019). Pathways of socio-ecological resilience to climate change for fisheries through indigenous knowledge, Human and Ecological Risk Assessment An International Journal, 25 (8), 2032-2044.

Jeans, H., Thomas, S., Castillo, G. (2016). The Future Is a Choice: The Oxfam Framework and Guidance for Resilient Development. Oxfam International: Oxford, UK.

Jongen, C., Langham, E., Bainbridge, R., \& McCalman, J. (2019) Instruments for Measuring the Resilience of Indigenous Adolescents: An Exploratory Review. Front, Public Health, 7 (194), 1-14.

Kelley, T. (2013). Environmental Health Resilience, Environmental Health Insights, 7, 2931.

Kobarsih, M., \& Siswanto, N. (2018). Penanganan Susut Panen dan Pasca Panen Padi Kaitannya dengan Anomali Iklim di Wilayah Daerah Istimewa Yogyakarta, Planta Tropika Journal of Agro Science, 3 (2), 100-106. 
Kuyu, C.G., \& Bereka, T.Y. (2019). Review on contribution of indigenous food preparation and preservation techniques to attainment of food security in Ethiopi, Food Science and Nutrition, 8 (1), 1-13.

Leite, M., Ross, H., \& Berkes, F. (2019). Interactions between individual, household, and fishing community resilience in southeast Brazil, Ecology and Society 24 (3), 2.

Lunga, W., \& Musarurwa, C. (2016). Indigenous food security revival strategies at the village level: The gender factor implications, Jàmbá: Journal of Disaster Risk Studies, $8(2), 1-17$.

Mavhura, E. (2017). Building resilience to food insecurity in rural communities: Evidence from traditional institutions in Zimbabwe, Jàmbá: Journal of Disaster Risk Studies, 9 (1),1-9.

McCubbin, S. G., Pearce, T., Ford, J.D., \& Smit, B. (2017). Social-ecological change and implications for food security in Funafuti, Tuvalu, Ecology and Society 22 (1),53.

Mohajan, H.K. (2018). Qualitative Research Methodology in Social Sciences and Related Subjects, Journal of Economic Development, Environment and People, 7 (1), 23-48.

Nopianti, R. (2016). Leuit Si Jimat: Wujud Solidaritas Sosial Masyarakat Di Kasepuhan Sinarresmi, Patanjala, 8 (2), 219 - 234.

Nuno, L., Raka, I.G.N., \& Yuswanti, R.H. (2017). Pengaruh Penundaan Waktu Prosesing Terhadap Mutu Benih Padi (Oryza sativa 1.) Varietas Membramo, EJurnal Agroekoteknologi Tropika, 6 (3), 259-268.

O'cornor, D., Noyles, P., Ilcan, S., Oliver, M. (2016). Living with insecurity: Food security, resilience, and the World Food Programme (WFP), Global Social Policy 17 (1), 1-18.

Ohleky, M.P., Pattiselanno, A.E., \& Kaplale, R. (2017). Namlai Kerne: Kearifan Lokal Dan Ketahanan Pangan Masyarakat Desa Werwaru Kecamatan Moa Kabupaten Maluku Barat Daya, Agrilan: Jurnal Agribisnis Kepulauan, 5 (2),114-131.

Östh, J., Dolciotti, M., Reggiani, A., \& Nijkamp, P. (2018). Social Capital, Resilience and Accessibility in Urban Systems: a Study on Sweden, Netw Spat Econ, 18 (2), 313-336.

Puspitasari, C. (2018). Cultural Resilience In Kampung Mahmud As An Effort To Preserve Historic Area. Jurnal of Islamic Architecture 5 (3):151-158.

Raheem, D. (2018). Food and Nutrition Security as a Measure of Resilience in the Barents Region, Urban Science, 2 (72),1-15.

Salomon, A. K., Quinlan, A.E., Pang, G.H., Okamoto, D.K., and Vazquez-Vera, L. ( 2019). Measuring social-ecological resilience reveals opportunities for transforming environmental governance, Ecology and Society, 24 (3),16.

Schipanski, M. E., Graham, K., MacDonald., et al. (2016). Realizing resilient food systems, BioScience, 66 (7), 600-610.

Sugiyono. (2016). Metode Penelitian Kuantitatif Kualitatif dan R\&D. Alfabeta:Bandung.

Suwati, Wiryono, B., \& Romansyah, E. (2018). Analisis Susut Hasil Padi Pada Lahan Kering Dan Implikasinya Terhadap Perekonomian Di Kabupaten Lombok Tengah, Jurnal Ulul Albab, 22 (2), 105-109.

Tamitiadini, D., Dewi, W.W.A., \& Adila, I. (2019). Inovasi Model Mitigasi Bencana Non Struktural Berbasis Komunikasi, Informasi, Koordinasi Dan Kerjasama. Komunikasi XIII (01), 41-52.

Tammar, A., Abosuliman, S.S., \& Rahaman, K.R. (2020). Social Capital and Disaster Resilience Nexus: A Study of Flash Flood Recovery in Jeddah City, Sustainability 12 (4668), 1-6. 
Tarusarira, J., \& Manyena, B. (2016). Reconciliation in Zimbabwe: Building Resilient Communities or Unsafe Conditions?, Journal of Conflict Transformation E Security, $5(1), 54-74$.

Tendal, D.M., Joerin, J., Kopainsky, B., et al. (2015). Food system resilience: Defining the concept, Global Food Security, (6), 17-23.

Tremblay, R., Landry-Cuerrier, M., \& Humphries, M.M. (2020). Culture and the socialecology of local food use by Indigenous communities in northern North America, Ecology and Society, 25(2), 8

Ulrichs, M., Slater, R., \& Costella, C. (2019). Building resilience to climate risks through social protection: from individualised models to systemic transformation. Disasters, 43 (S3), S368-S387.

Ungar, M. (2018). Systemic resilience: principles and processes for a science of change in contexts of adversity, Ecology and Society, 23 (4), 34.

Valés-Planells, M., Galiana, F., \& Díez-Torrijos, I. (2019). Agricultural abandonment and resilience in a Mediterranean periurban traditional agroecosystem: a landscape approach, Ecology and Society, 25 (1), 5.

Veronika, L. (2013). Memahami Sistem Pengetahuan Budaya Masyarakat Pegunungan Tengah, Jayawijaya, Papua dalam Konteks Kebencanaan, Antropologi Indonesia 34 (2), 134-151.

Wenger, C. (2017). The oak or the reed: how resilience theories are translated into disaster management policies, Ecology and Society, 22 (3), 18.

Wiradimadja, A. (2018). Kearifan Lokal Masyarakat Kampung Naga Sebagai Konservasi Alam Dalam Menjaga Budaya Sunda. Jurnal Sosiologi Pendidikan Humanis 3 (1), 1-8.

Worstell, J., \& Green, J. (2017). Eight qualities of resilient food systems: Toward a sustainability/resilience index, Journal of Agriculture, Food Systems, and Community Development, 7(3), 23-41. 